\title{
Development of partial abiotic stress tolerant Citrus reticulata Blanco and Citrus sinensis (L.) Osbeck through Agrobacterium- mediated transformation method
}

Nazmul Hasan', Mohammad Kamruzzaman', Shariful Islam², Hammadul Hoque ${ }^{1}$, Fahmid Hossain Bhuiyan ${ }^{1}$ and Shamsul H. Prodhan ${ }^{1 *}$ (D)

\begin{abstract}
Background: Recent studies indicate that farmers are facing several challenges due to biotic and abiotic stresses like diseases, drought, cold, and soil salinity which are causing declined Citrus production. Thus, it is essential to improve these varieties which would be resistant against biotic and abiotic stresses as well as high yielding. The transformation of abiotic stress tolerant genes in Citrus species is essential for using areas affected by abiotic stresses. This study was aimed to improve resistance of Citrus reticulata Blanco and Citrus sinensis (L.) Osbeck to abiotic stresses by transferring PSCBL and PSCIPK genes through Agrobacterium-mediated transformation.

Results: Abiotic stress tolerant PSCBL and PSCIPK genes isolated from Pisum sativum were transformed into two Citrus species, Citrus reticulata Blanco and Citrus sinensis (L.) Osbeck, through Agrobacterium-mediated transformation method. Mature seed-derived calli of two Species were infected with Agrobacterium tumefaciens LBA4404 harboring PSCBL and PSCIPK genes. The infected calli were co-cultured in dark condition and later on washed with antibiotic solution and transferred to selection medium. Preliminary resistant calli were recovered and regenerated to plantlets. Maximum regeneration rate was $61.11 \pm 1.35 \%$ and $55.55 \pm 1.03 \%$, respectively. The genetic transformation was confirmed by performing $\beta$ glucuronidase (GUS) assays and subsequent PCR amplification of the GUS gene. The transformation rates of the two cultivated species were higher than previous reports. Maximum transformation frequencies were found when bacterial $\mathrm{OD}_{600}$ was 0.5 and concentration of acetosyringone was 150 $\mu \mathrm{M}$. In-vitro evaluation of drought and salt tolerance of transgenic plantlets were done, and transgenic plantlets showed better performance than the control plants.

Conclusions: The present study demonstrates that transformation of Citrus plants with PSCBL and PSCIPK genes result in improved abiotic stress tolerance.
\end{abstract}

Keywords: Citrus, Agrobacterium, Transformation, Regeneration, PCR, Abiotic stress

\footnotetext{
* Correspondence: shamsulhp@yahoo.com

'Department of Genetic Engineering and Biotechnology, Shahjalal University

of Science and Technology, Sylhet 3114, Bangladesh

Full list of author information is available at the end of the article
} 


\section{Background}

The genus Citrus includes more than 162 species belonging to the order Geraniales, family Rutaceae and subfamily Aurantoideae. Citrus reticulata Blanco and Citrus sinensis (L.) Osbeck are two primitive species of Citrus. Citrus sinensis also known as Sweet-orange or Malta, is the most cultivated Citrus in the world which accounts for about $70 \%$ of the total production. Citrus reticulata Blanco is a species of Citrus also known as Mandarin, Tangerine, Unshu orange, Comola etc in the Asian Subcontinent. Citrus reticulata Blanco and Citrus sinensis (L.) Osbeck, both are grown in tropical and semi-tropical areas around the globe for its sweet, juicy, and nutritious fruits. Orange farming has been extending rapidly in some regions of Bangladesh like Sylhet, Panchagarh, Chattogram, and Thakurgaon. Recent studies indicate that farmers are facing several problems due to biotic and abiotic stresses like diseases, drought, cold, and soil salinity which are causing declined Citrus production. Thus, it is essential to improve these varieties which would be resistant against biotic and abiotic stresses and would be high yielding. Traditional breeding methods have been used successfully over the years to improve Citrus; however, these methods are limited by slow growth, incompatibility, polyembryony, parthenocarpy etc and traditional breeding takes a long time for the incorporation of desirable traits. In-vitro culture made it easy to improve Citrus against different abiotic stresses, diseases, low-yield through exploiting somaclonal variations, somatic cell hybridization [1, 2], transformation of high yielding cultivars [3] and also to conserve important Citrus genotypes. In plants, the $\mathrm{Ca}^{2+}$ is involved in almost all biological processes. Calcium serves as a ubiquitous secondary messenger and regulates a multitude of physiological and developmental processes, including responses to abiotic stress, pathogen defense, and adjustment of ion homeostasis [4-6]. In response to environmental and developmental stimuli, plant cells react with specific temporal changes in cytosolic calcium $\left(\mathrm{Ca}^{2+}\right)$ concentration. $\mathrm{Ca}^{2+}$ can serve simultaneously as a messenger and a regulator in so many different processes, that it raises the fundamental question of how specificity in information processing and output determination can be achieved [7-9]. The families of calcineurin B-like (CBL) proteins represent a unique group of calcium sensors and contribute to the decoding of calcium transients by interacting with and regulating the family of CBL-interacting protein kinases (CIPKs). In higher plants, CBL proteins and CIPKs form a complex signaling network that allows for flexible but specific signal response coupling during environmental adaptation reactions [10]. The CBL-CIPK network helps to maintain proper ion balance when abiotic stresses occur. The CBL and CIPK homolog are present in all green lineages, and phylogenomic analysis suggests their expansion from a single CBL-CIPK pair present in the ancestor of modern plants and algae [10]. Thus, the incorporation of these two key genes into the desired plants would improve the resistance against abiotic stresses. This study was aimed to develop resistance of Citrus reticulata Blanco and Citrus sinensis (L.) Osbeck to abiotic stresses by transferring PsCBL and PsCIPK genes through Agrobacterium-mediated transformation.

\section{Methods}

\section{Plant materials and media}

Orange species Citrus reticulata Blanco and Citrus sinensis (L.) Osbeck was collected from Citrus Research Station, Jaintapur, Sylhet, Bangladesh, and identification and confirmation of collected samples were done by J.C. Sarker, Senior Scientific Officer, Citrus Research Station, Jaintapur, Sylhet, Bangladesh. The healthy and good quality mature seeds from these orange cultivars were collected. Dehusked mature seeds were sterilized with $70 \%$ ethanol for 5 mins, $0.1 \% \mathrm{HgCl}_{2}$ and Tween 20 for 2 mins, followed by washing with autoclaved distilled water and then dried on sterilized filter paper. The culture medium used in this study was based on MS [11] basal salts and vitamins (Table 1). All plant samples handled in this experiment were maintained in specific culture room to avoid any direct contact with environment, and all the used chemicals and plant materials were discared following bio-safety guideline provided by institute.

\section{Agrobacterium strains and culture conditions}

The transformation studies were carried out with Agrobacterium tumefaciens LBA4404 harboring the binary vector pBI121/PsCBL and pBI121/PsCIPK containing abiotic stress tolerant $P_{S} C B L$ and $P s C I P K$ genes, respectively, uidA gene encoding $\beta$-glucuronidase (GUS) and nptII gene encoding neomycin phosphotransferase II conferring kanamycin resistance [12-14]. The single colonies of both strains were cultured in liquid YEP medium containing $100 \mathrm{mg} / \mathrm{l}$ kanamycin and grown in a shaker at $200 \mathrm{rpm}$ in dark at $28{ }^{\circ} \mathrm{C}$ for $48 \mathrm{~h}$ until the $\mathrm{OD}_{600}$ reached between 0.4 and 0.8 . The bacterial cells were collected with centrifugation at $8000 \mathrm{rpm}$ for 5 mins and suspended in MS resuspension medium in an appropriate ratio to adjust $\mathrm{OD}_{600}$ to 0.5 and then different concentrations of acetosyringone (100, 150, and 200 $\mu \mathrm{M})$ were added.

\section{Callus induction}

The sterilized seeds were inoculated in test tube on MS medium containing 2,4-D at different concentrations ( 0 , $0.5,1.0,1.5,2.0,2.5,3.0,3.5,4.0,5.0 \mathrm{mg} / \mathrm{l})$ and incubated at $25 \pm 1{ }^{\circ} \mathrm{C}$ in $2000 \mathrm{~lx}$ light. Fifty seeds were inoculated per replication, and experiments were repeated three times. After 3 weeks only yellowish white colored globular 
Table 1 The composition of different media used in this transformation study

\begin{tabular}{|c|c|}
\hline Media & Composition of the media \\
\hline Callus induction media & $\begin{array}{l}\text { MS medium supplemented with different concentrations } \\
\text { of } 2.4-\mathrm{D}(0,0.5,1.0,1.5,2.0,2.5,3.0,3.5,4.0,5.0 \mathrm{mg} / \mathrm{l})\end{array}$ \\
\hline MS resuspension media & $\begin{array}{l}\text { MS salts and vitamins were supplemented with } 68 \mathrm{~g} / \mathrm{l} \text { sucrose, } \\
36 \mathrm{~g} / \mathrm{l} \text { glucose, } 3 \mathrm{~g} / \mathrm{l} \mathrm{KCl}, 4 \mathrm{~g} / \mathrm{l} \mathrm{MgCl} \text {, and } \mathrm{dH}_{2} \mathrm{O} . \mathrm{pH} \\
\text { was adjusted to } 5.2 \text {. }\end{array}$ \\
\hline Infection medium & $\begin{array}{l}\text { Infection medium was prepared by adding bacterial culture in } \\
\text { MS resuspension medium in an appropriate ratio to adjust } \mathrm{OD}_{600} \text { to } 0.5 \text {. }\end{array}$ \\
\hline Co-cultivation media & $\begin{array}{l}\text { MS medium was fortified with } 30 \mathrm{~g} / \mathrm{l} \text { sucrose, } 10 \mathrm{~g} / \mathrm{l} \text { glucose, } \\
3.0 \mathrm{mg} / \mathrm{l} \text { 2,4-D and } \mathrm{dH} \mathrm{H}_{2} \mathrm{O} \text {. } \mathrm{pH} \text { was adjusted to } 5.2 \text {. After autoclaving } \\
\text { the } \mathrm{MS} \text { medium different concentrations of filter-sterilized acetosyringone } \\
(0 \mu \mathrm{M}, 100 \mu \mathrm{M}, 150 \mu \mathrm{M} \text {, and } 200 \mu \mathrm{M}) \text { were added. }\end{array}$ \\
\hline Selection media & $\begin{array}{l}\text { MS medium was supplemented with } 30 \mathrm{~g} / \mathrm{l} \text { sucrose and } 3.0 \mathrm{mg} / \mathrm{l} \text { 2,4-D } \\
\text { followed by adjustment to the required volume with } \mathrm{dH} \mathrm{H}_{2} \mathrm{O} \text { and pH adjustment } \\
\text { to } 5.8 \text {. After autoclave filter sterilized kanamycin } 100 \mathrm{mg} / \mathrm{l} \text { was added. }\end{array}$ \\
\hline Regeneration media & MS medium supplemented with different concentrations of BA and NAA. \\
\hline Rooting medium & MS medium containing no hormone. \\
\hline
\end{tabular}

calli were selected and cut into small pieces and subcultured onto fresh callus induction medium (Table 1) for infection with Agrobacterium.

\section{Infection with Agrobacterium and co-culture}

Fresh calli were taken from previous experiment and subjected to infection by immersing them in the infection medium containing the LBA4404 strain having pBI121/PsCBL sense vector and LBA4404 strain having pBI121/PsCIPK sense vector for 90 mins with intermittent gentle shaking and dried on sterile filter paper for 30 mins. The infected calli were cultured on cocultivation medium (Table 1 ) for 3 days in dark conditions at $25{ }^{\circ} \mathrm{C} \pm 1{ }^{\circ} \mathrm{C}$. The co-cultivation medium was fortified with $0,100,150$, and $200 \mu \mathrm{M}$ acetosyringone to determine the optimum concentration of acetosyringone to increase the transformation efficiency.

\section{Washing and inoculation in selection medium}

After the appearance of slight growth of Agrobacterium around most of the calli were rinsed 8-10 times in sterile distilled water. Followed by washing with sterile distilled water, the calli were washed with the washing solution containing cefotaxime (500, 600, 700, and 800 $\mathrm{mg} / \mathrm{l}$ ) for 5 mins. The antibiotic treated calli were washed with sterile distilled water and dried on sterile filter paper. Then, the calli were transferred onto the selection medium and incubated for 15 days at $25 \pm 1{ }^{\circ} \mathrm{C}$ in dark. After that, the calli were again sub-cultured on the selection media (Table 1) for 7 days and incubated in $25 \pm 1^{\circ} \mathrm{C}$ in dark.

\section{Regeneration of putative transformants and In-vitro evaluation}

Fresh and growing calli from the second selection medium were transferred to regeneration medium containing different concentrations and combinations of $\mathrm{BA}$ and NAA and were incubated at $25 \pm 1{ }^{\circ} \mathrm{C}$ in white fluorescent light under $16-\mathrm{h}$ photoperiods and subcultured on the same media after 14 days. Shoot proliferation started after 3 weeks and the regenerated shoots were shifted to the rooting media and were maintained at $25 \pm 1{ }^{\circ} \mathrm{C}$ in white fluorescent light under $16-\mathrm{h}$ photoperiods. In-vitro evaluation of kanamycin resistantregenerated plantlets was done in MS medium supplemented with different concentrations of $\mathrm{NaCl}$ (50, 100, 150, and $200 \mathrm{mM}$ ) and $3 \mathrm{mg} / \mathrm{l}$ PEG. Tolerant plants

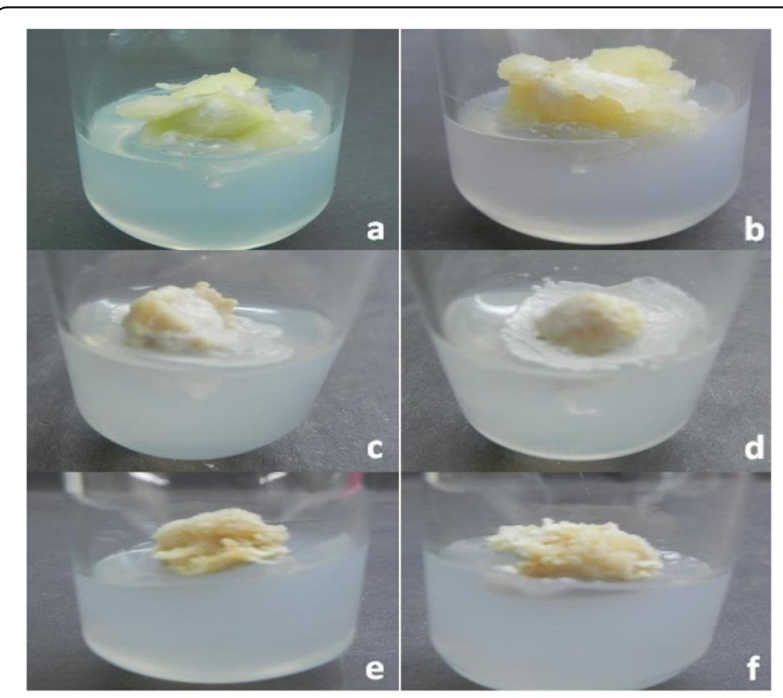

Fig. 1 Calli infected with Agrobacterium and washed with antibiotic. a calli induced from Citrus reticulata Blanco; $\mathbf{b}$ calli induced from Citrus sinensis (L.) Osbeck; c infected calli of Citrus reticulata Blanco; $\mathbf{d}$ infected calli of Citrus sinensis (L.) Osbeck; e: antibiotic-treated calli of Citrus reticulata Blanco, and $\mathbf{f}$ antibiotic-treated calli of Citrus sinensis (L.) Osbeck 


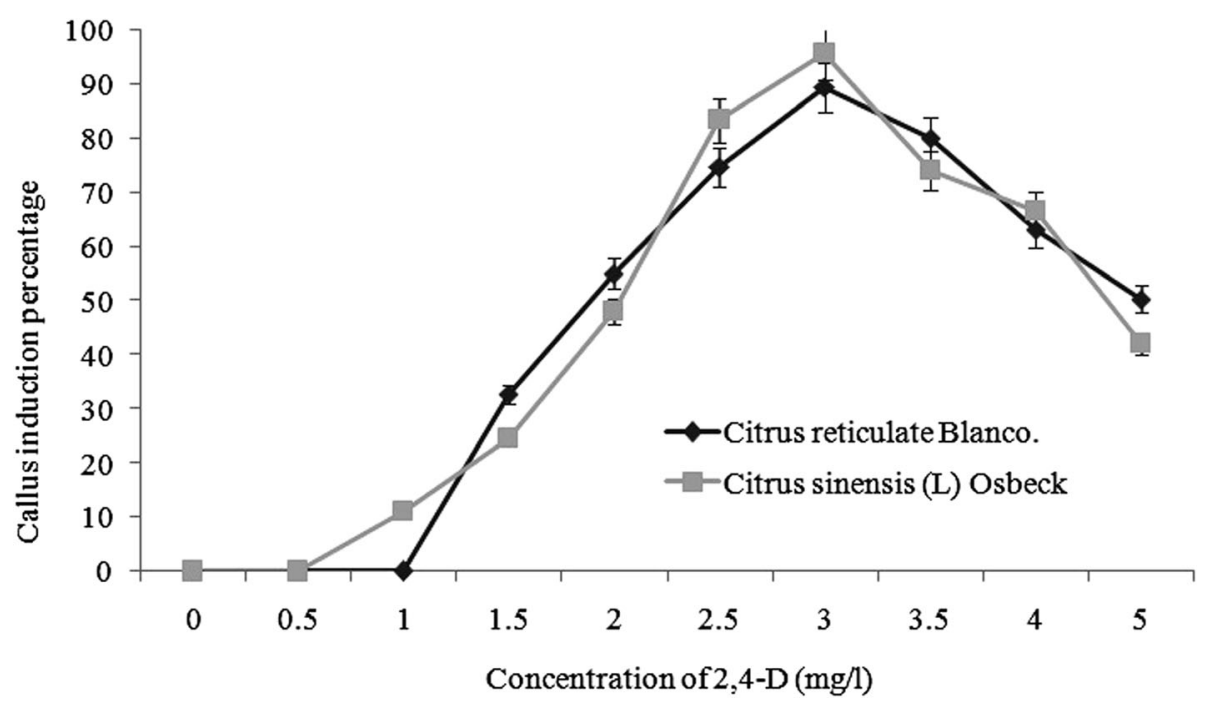

Fig. 2 Role of 2,4-D on callus induction in Citrus reticulata Blanco and Citrus sinensis (L.) Osbeck

were maintained under controlled conditions by subculturing at an interval of 21 days regularly.

\section{GUS histochemical assay of transformed callus}

GUS activity was detected as described by Jefferson et al. (1987). Randomly kanamycin-resistant calli of two Citrus species were taken from selection medium and washed with autoclaved distilled water to remove adjacent media. The calli were incubated in X-glucuronide (5-bromo-4-

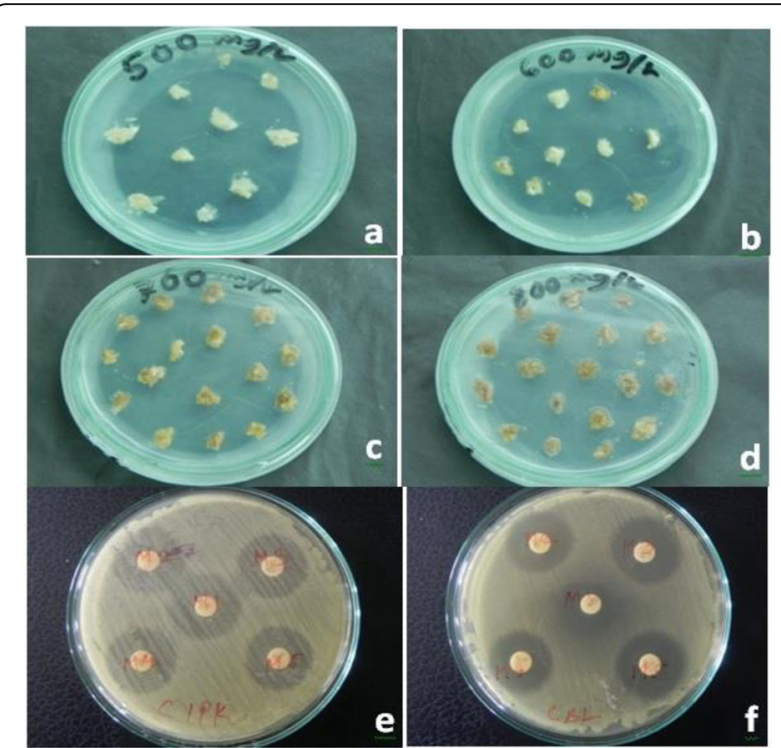

Fig. 3 Antibiotic sensitivity test of explants and antibiogram of Agrobacterium strains. After seven days of inoculation of explants remained fresh (a) at $500 \mathrm{mg} / \mathrm{l}$ cefotaxime but became pale (b) at $600 \mathrm{mg} / \mathrm{l}$ cefotaxime and died at $700 \mathrm{mg} / \mathrm{l}, 800 \mathrm{mg} / \mathrm{l}(\mathrm{c}, \mathrm{d})$. Clear zone were found at $500 \mathrm{mg} / \mathrm{l}$ cefotaxime in case of both strains PSCIPK (e) and PSCBL (f). chloro-indoyl $\beta$-D glucuronide) staining solution at $37{ }^{\circ} \mathrm{C}$ for $24 \mathrm{~h}$ in dark. The $\mathrm{X}$-glucuronide was broken down by the activity of $\beta$-glucuronidase (GUS) gene, which was transferred to the cells of calli by Agrobacterium tumefaciens. The stained tissues were rinsed several times with $75 \%$ ethanol. Calli stained with indigogenic dye were scored, and stable GUS expression was tested in kanamycin-resistant calli. The transformation efficiency was calculated by percent of GUS-positive calli.

\section{PCR analysis of transformed regenerated plantlets}

The genomic DNA of kanamycin-resistant regenerated plantlets (putative) and control plants of two Citrus species were extracted from the leaves by using the modified CTAB method [15]. The 600 bp fragments of the GUS gene were amplified using the following set of primer: Forward 5'TTTGCAAGTGGTGAATCCCGACCT-3' and Reverse 5'AGTTTACGCGTTGCTTCCGCC AGT-3' [16]. The PCR reaction was carried out in $25-\mu \mathrm{l}$ mixture containing $2.5 \mu \mathrm{l} \mathrm{10X} \mathrm{Taq} \mathrm{buffer,} 1.5 \mu \mathrm{l} 25 \mathrm{mM} \mathrm{MgCl}_{2}$,

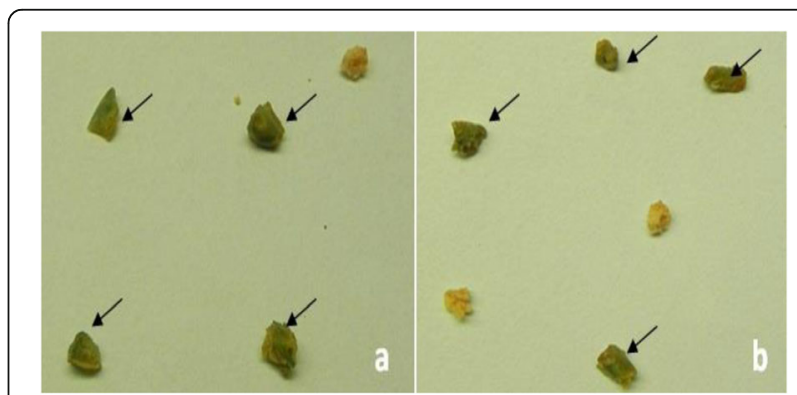

Fig. 4 Assay of GUS activity in transformed calli of Citrus reticulata Blanco (a) and Citrus sinensis (L.) Osbeck (b). Arrow indicates the GUS-positive calli (blue spot) 


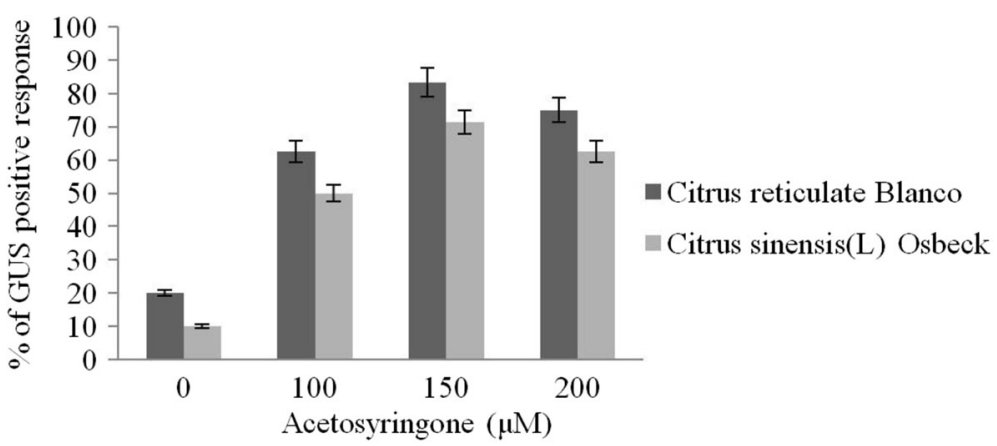

Fig. 5 GUS assay of the putatively transformed calli in different concentrations of acetosyringone

$1.0 \mu \mathrm{l}$ dNTPs mix, $6.25 \mu \mathrm{l} 2 \mu \mathrm{M}$ Forward primer, $6.25 \mu \mathrm{l} 2$ $\mu \mathrm{M}$ Reverse primer, $0.2 \mu \mathrm{l}$ Taq DNA polymerase $(5 \mathrm{U} / \mu \mathrm{l})$, $2.3 \mu \mathrm{l}$ Sterile $\mathrm{ddH}_{2} \mathrm{O}$ and $5.0 \mu \mathrm{l}$ Template DNA. The PCR reaction conditions were initial denaturation at $95{ }^{\circ} \mathrm{C}$ for 5 mins, 35 cycles of denaturation at $95{ }^{\circ} \mathrm{C}$ for $1 \mathrm{~min}$, annealing at $54{ }^{\circ} \mathrm{C}$ for $1 \mathrm{~min}$, extension at $72{ }^{\circ} \mathrm{C}$ for 2 mins, and the final extension at $72{ }^{\circ} \mathrm{C}$ for 10 mins. The PCR products were confirmed by running in $1.4 \%$ agarose gel ectrophoresis in $1 \mathrm{X}$ TBE buffer. $2.0 \mu \mathrm{l}$ loading dye was mixed with PCR products and loaded in the wells. A marker DNA (1 Kb Sharp DNA Ladder Marker, RBC Bioscience Corporation) was also loaded on one side of the gel and electrophoresis was conducted at $75 \mathrm{~V}$ for 50 mins. After completion of electrophoresis, the gel was stained in ethidium bromide for $2 \mathrm{~h}$ and placed on UV transilluminator in Gel Documentation System. Finally, the photograph was captured (Nikon D5300).

\section{Statistical analysis}

All the experimental data were collected at regular intervals for analysis and reckoned under statistical basis. Arithmetic mean (A.M.) and standard deviation (S.D.) were calculated by analyzing the data with Microsoft Excel 2007. Standard error (S.E.) was calculated by dividing standard deviation by square root of the total three replications for a single variety.

\section{Results}

Mature dehusked seeds from Citrus reticulata Blanco and Citrus sinensis (L.) Osbeck were sterilized and inoculated on MS medium containing different concentrations of 2, 4-D. After 3 weeks of incubation, yellowish white, light green, and green colored globular calli were generated (Fig. 1). Maximum callus induction frequency of Citrus reticulata Blanco and Citrus sinensis (L.) Osbeck $89.33 \pm$ $3.03 \%$ and $95.67 \pm 4.04 \%$, respectively, was found when MS medium was supplemented with $3 \mathrm{mg} / \mathrm{l}$ 2,4-D (Fig. 2). Yellowish white colored globular calli were selected for transformation. The selected calli of both species were pre-cultured on the same media for 3 days. Then precultured calli were infected by immersing them in the infection medium (MS) containing both Agrobacterium strains for $90 \mathrm{~min}$ with intermittent gentle shaking and dried on sterile filter paper for 30 minutes. After 3 days of co-culture in dark on co-culture medium, calli were washed with $500 \mathrm{mg} / \mathrm{l}$ cefotaxime and transferred onto selection medium for fifteen days and was sub-cultured again on same selection medium (Fig. 1). The concentration of antibiotic was optimized via antibiogram of

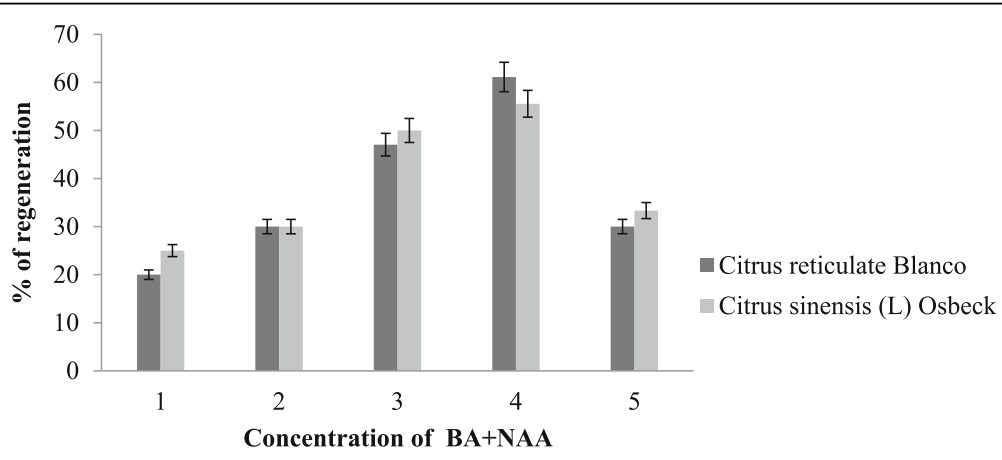

Fig. 6 Effect of $B A$ and NAA at different concentrations on regeneration of transformed calli Here, $1=2.0 \mathrm{BA}+1.0 \mathrm{NAA} ; 2=2.5 \mathrm{BA}+1.0 \mathrm{NAA} ; 3$ $=3.0 \mathrm{BA}+1.5 \mathrm{NAA} ; 4=3.0 \mathrm{BA}+2.0 \mathrm{NAA} ; 5=3.5 \mathrm{BA}+2.5 \mathrm{NAA} \mathrm{mg} / \mathrm{l}$ 
Agrobacterium strains and plant tissue sensitivity test (Fig. 3). At $500 \mathrm{mg} / \mathrm{l}$ cefotaxime, clear zones were found and no harmful effect on plant tissue (callus) was observed after 7 days of treatment. After the second sub-culture, the GUShistochemical assay was done and the frequency of GUSpositive calli was $83.33 \pm 2.42 \%$ and $43 \pm 2.00 \%$ for both species respectively (Fig. 4). Maximum GUS-positive results were found when $150-\mu \mathrm{M}$ acetosyringone was added to the co-culture media and incubated for 3 days (Fig. 5). The fresh kanamycin-resistant calli were then transferred to the regeneration medium and sub-cultured on same media at an interval of 21 days. After 4 weeks of inoculation on regeneration medium, shoot (2-10 shoot per callus) generation started (Fig. 6). The frequencies of shoot induction were $61.11 \pm 1.35 \%$ and $55.5 \pm 1.03 \%$ for both species respectively, when MS medium was supplemented with $3.0 \mathrm{mg} / \mathrm{l}$ of BA and $2 \mathrm{mg} / \mathrm{l}$ of NAA (Fig. 7). The shoots obtained from differentiation of callus were taken and cultured on rooting medium [17]. Roots appeared within 20 days of inoculation. The genomic DNA was isolated from leaves of the putative transformed plantlets and nontransformed control plants and run on a $0.8 \%$ agarose gel for each sample (Fig. 8a). Transformation at genomic level was detected by amplifying GUS gene. Specific primers were used in PCR analysis to verify the presence of transgenes (GUS). Transgenic plantlets of both species produced bands of the expected size of 600 bp (Fig. 8b), whereas the corresponding bands were not found in control plants. The presence of reporter gene at the genomic level confirms the transformation of abiotic stress tolerant

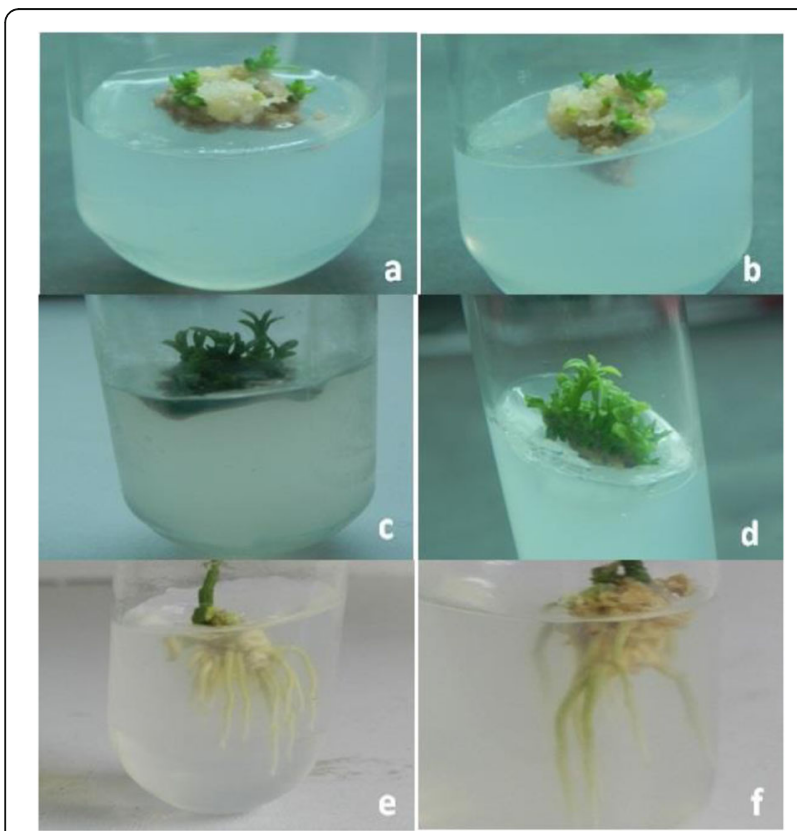

Fig. 7 Shoot and root induction from kanamycin resistant explants on MS medium of Citrus reticulata Blanco $(\mathbf{a}, \mathbf{c}, \mathbf{e})$ and Citrus sinensis (L.) Osbeck (b, d, f)

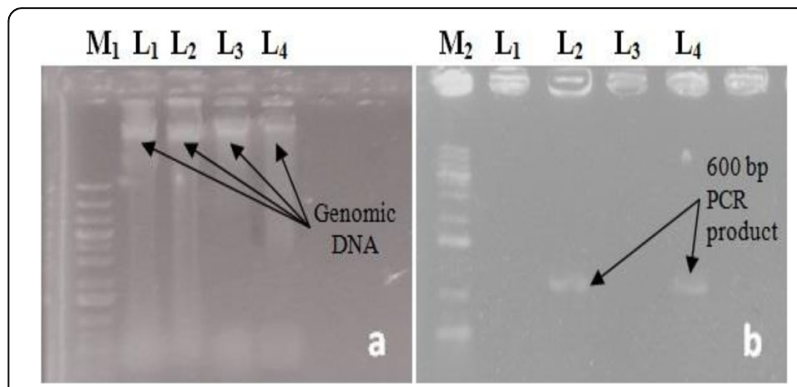

Fig. 8 a Represents the genomic DNA and $\mathbf{b}$ represents the PCR product of the GUS gene. Lane $M_{1}: 1$ kb plus ladder DNA and $M_{2:} 1$ kb ladder DNA; $L_{1}$ : DNA of control Citrus reticulata Blanco. $L_{2}$ : DNA of transformed Citrus reticulata (L.) Blanco. $L_{3}$ : DNA of control Citrus sinensis (L.) Osbeck. $L_{4}$ : DNA of transformed Citrus sinensis (L.) Osbeck

genes in two Citrus species. This result confirms the stable transformation of the transgenes and successful integration in the genome. In-vitro evaluations of the transgenic plants were performed in MS medium supplemented with different concentrations of $\mathrm{NaCl}(50,100,150$, and $200 \mathrm{mM})$. The transgenic plantlets of two species remained fresh and survived for more than 4 weeks on MS medium supplemented with $50 \mathrm{mM} \mathrm{NaCl}, 2$ weeks on 100 and $150 \mathrm{mM}$ $\mathrm{NaCl}$, and 1 week on $200 \mathrm{mM} \mathrm{NaCl}$ but control plantlets became pale within 5-7 days and died after 10 days (Fig. 9). These results confirm the expression of stress tolerant genes in these Citrus species.

\section{Discussion}

In this research, Agrobacterium-mediated $P S C B L$ and PsCIPK genes were transferred to citrus species, Citrus reticulata Blanco, and Citrus sinensis (L.) Osbeck using mature seed-derived calli. The previous study [18] reported that mature seed-derived callus was the most amenable explants for Agrobacterium-mediated transformation. Differences between various hormone supplementations were observed in callus induction. The efficiency of the Agrobacterium-mediated transformation method was inspected through vigilant observations of the effects of several parameters considered to be critical. The success of transformation was assessed by the percentage of blue spots signifying transient expression of GUS gene and the PCR detection of GUS gene. The density of Agrobacterium directly affects transformation efficiency since gene transfer only occurs with proper Agrobacterium attachment to plant cells. Therefore, high Agrobacterium concentration increased the number of plant cells being infected [19]. In this study, the highest number of GUS staining was observed in Agrobacterium suspension $\mathrm{OD}_{600}$ at 0.5. More concentrated Agrobacterium suspension (when $\mathrm{OD}_{600}$ was $0.8-1.0$ ); however, significantly reduced the number of transformed cells due to the fact that intense Agrobacterium infection caused severe damage to the plant cells. The previous study [19] reported 


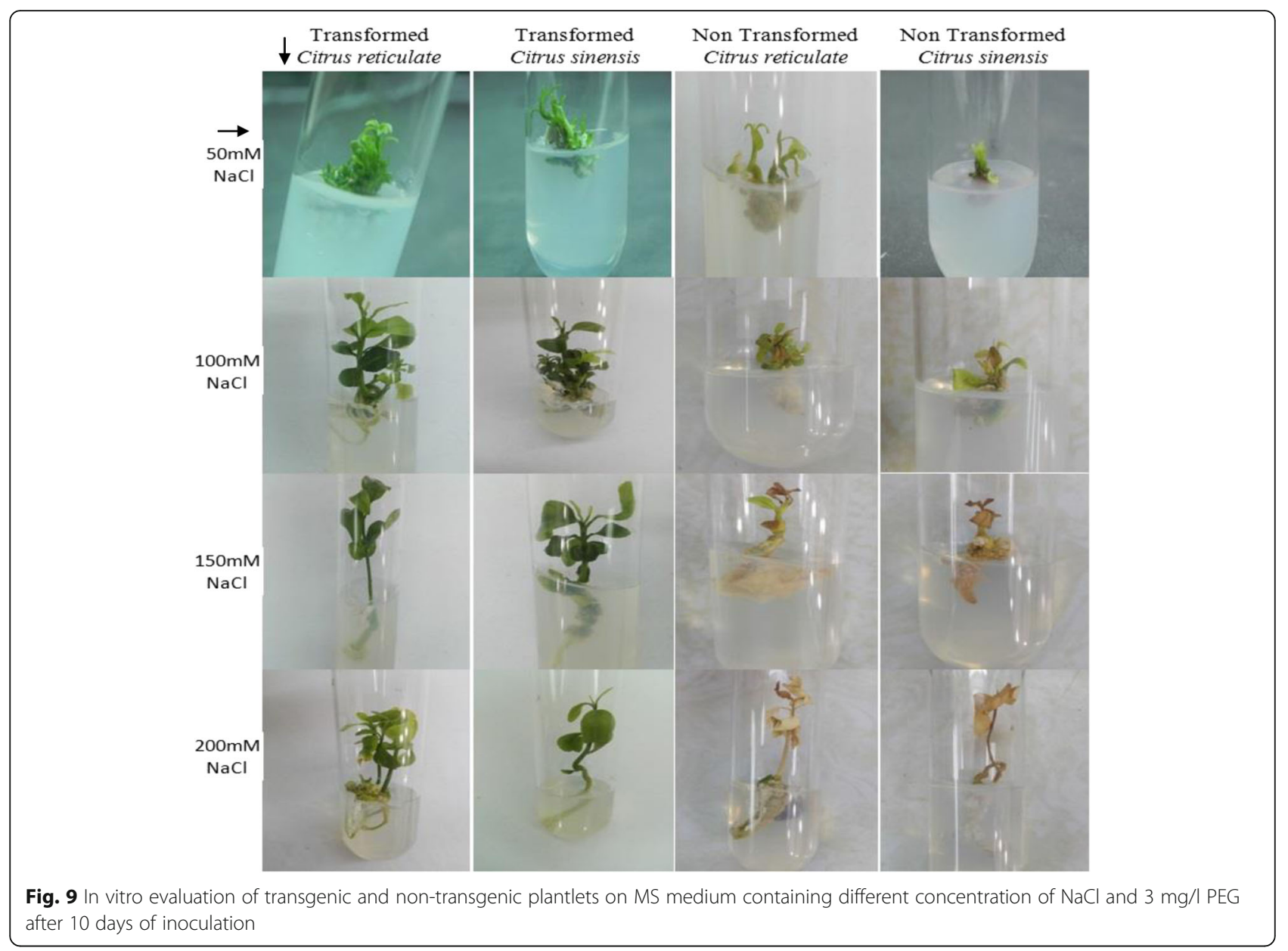

that bacteria concentration at $\mathrm{OD}_{600} 0.6$ to 0.8 was the most efficient in sweet potato embryogenic callus Agrobacterium-mediated transformation. Karami, 2008 [20] also reported that Agrobacterium concentration for transformation is dependent on multi-factors including Agrobacterium strain and viability, plant species, and cultivar and type of tissue used. The age of the callus is a crucial factor for transformation efficiency. Hiei and Komari, 2008 [21] reported that fresh and healthy immature embryos ensure the successful transformation. Young embryogenic callus is also favorable due to its higher regeneration ability as compared to old calli [22, 23]. Sharawat, 2007 defined the pre-culture period as the period that starts at the moment when immature embryos are first isolated and cultured immediately before Agrobacterium infection [24].

Zuraida et al. 2011 [25] showed that pre-culture period for more than 3 days improved transformation frequency. Four-day pre-cultured calli were used for Agrobacterium infection. During infection, the pre-culture calli were immersed in the infection medium for 90 mins with intermittent gentle shaking. The infected calli were dried for 30 mins on sterilized filter paper. Eighty-five transformation rate was recorded when calli were infected for 90 mins and dried for 30 mins [25]. In this study, infected calli were co-cultured for 3 days [25]. Zuraida et. al., 2011 stated a significant increase of transient GUS expressions were observed in 4 days of co-cultured calli but we found maximum GUS expression when co-cultured for 3 days. The influence of various acetosyringone concentrations $(0$, $100,150$, and $200 \mu \mathrm{M})$ in the co-culture medium were evaluated and significant GUS staining was achieved at the addition of $150 \mu \mathrm{M}$ acetosyringone. A similar result was obtained in the transformation of sweet potato when the effect of acetosyringone concentration in cocultivation medium was investigated [26]. After 3 days of co-cultured at the dark condition, the calli were washed with a washing solution containing $500 \mathrm{mg} / \mathrm{l}$ cefotaxime. The antibiotic concentration was selected through antibiogram of Agrobacterium and plant cell sensitivity test. Transient GUS gene expression was determined by GUS assay and PCR amplification of the GUS gene [27]. Almeida et al. 2003 stated that $81.5 \%$ GUS-positive result found in the Agrobacterium-mediated transformation of "Hamlin" sweet orange which is nearly similar to our result. Media composition, mainly the hormonal balance is an important factor influencing in-vitro culture initiation 
and plant regeneration from callus [28]. MS medium supplemented with $3 \mathrm{mg} / \mathrm{l}$ of 6-benzylaminopurine (BA) showed maximum regeneration efficiency for both Citrus species [29]. reported that the MS medium supplemented with $3 \mathrm{mg} \mathrm{L-1}$ of 6-benzylaminopurine (BA) showed maximum regeneration efficiency of the transformed explants. Shoots were rooted on MS medium without supplementation of hormone [29-32] and the rooted plantlets were evaluated on stress conditions. The transgenic plantlets showed moderate resistance against abiotic stresses like salt.

\section{Conclusion}

The demand of Citrus (orange) is increasing day by day in Bangladesh. A huge amount of foreign currency is being spent for importing orange. It is possible to grow Citrus commercially, fulfill the national demand, and save foreign currency by eliminating the problems by developing good varieties. In this research, a reliable and efficient transformation system for two Citrus species was developed and transgenic plants with stable integration of target genes were recovered. This study will help for the development of Citrus varieties with desired traits.

\section{Abbreviations \\ 2,4-D: 2,4-Dichlorophenoxyacetic acid; BA: 6-Benzylaminopurine; GUS: $\beta$ - glucuronidase; MS: Murashige and Skoog; NAA: 1-Naphthaleneacetic acid; nptll: Neomycin phosphotransferase II; OD 600 : Optical density at 600 nanometer UV light; PCR: Polymerase chain reaction; PsCBL: Calcineurin B-like protein of Pisum sativum; PSCIPK: CBL-interacting protein kinases of Pisum sativum; UV: Ultraviolet}

\section{Acknowledgements \\ The authors are thankful to the Department of Genetic Engineering and Biotechnology, Shahjalal University of Science \& Technology, Sylhet, Bangladesh, for providing laboratory facilities and Dr. Narendra Tuteja for providing two Agrobacterium tumefaciens strains harboring PsCIPK and PSCBL genes.}

\section{Authors' contributions}

$\mathrm{NH}$ and SHP conceived and designed the experiments. $\mathrm{NH}$ analyzed the data $\mathrm{NH}$ and $\mathrm{MK}$ performed the experiment, $\mathrm{NH}$ and $\mathrm{FHB}$ wrote the manuscript, $\mathrm{SI}$ and $\mathrm{HH}$ reviewed and revised the manuscript, and SHP supervised and validated the data. All authors have read and approved the manuscript.

\section{Funding}

The research was conducted with financial support of the Ministry of Science and Technology, Government of People's Republic of Bangladesh.

\section{Availability of data and materials}

Authors declare that all generated and analyzed data are included in the article.

\section{Ethics approval and consent to participate}

Not applicable

\section{Consent for publication}

Not applicable

\section{Competing interests}

The authors declare that they have no competing interests..

\section{Author details}

Department of Genetic Engineering and Biotechnology, Shahjalal University of Science and Technology, Sylhet 3114, Bangladesh. ${ }^{2}$ Department of Molecular Biology and Genetic Engineering, Sylhet Agricultural University, Sylhet 3100, Bangladesh.

Received: 19 September 2019 Accepted: 24 October 2019

Published online: 16 December 2019

\section{References}

1. Kobayashi, S. 1994. Production of novel varieties through protoplast fusion in fruit trees. Research Journal of Food and Agriculture (Japan),.

2. Liu, Yong-Zhong, and Xiu-Xin Deng. 2007. Citrus breeding and genetics in China. The Asian and Australasian Journal of Plant Science and Biotechnology 1 (1): 23-28. http://www.globalsciencebooks.info/JournalsSup/images/ Sample/AAJPSB_1(1)23-28.pdf.

3. Koltunow AM, Brennan P, Protopsaltis S, Nito N (2000) Regeneration of west indian limes (Citrus aurantifolia) containing genes for decreased seed set. Acta Hortic 3535:81-92 https://doi.org/10.17660/ActaHortic.2000.535.8

4. Kim MC, Chung WS, Yun DJ, Cho MJ (2009) Calcium and calmodulinmediated regulation of gene expression in plants. Molecular Plant 2(1):13-21 https://doi.org/10.1093/mp/ssn091

5. Sanders, Dale, Jérôme Pelloux, Colin Brownlee, and Jeffrey F Harper. 2002. Calcium at the crossroads of signaling calcium signals: a central paradigm in. Plant Cell, 401-417. https://doi.org/10.1105/tpc.002899.Calcium.

6. White PJ, Broadley MR (2003) Calcium in plants. Annals of Botany 92(4):487511 https://doi.org/10.1093/aob/mcg164

7. Hetherington AM, Brownlee C (2004) The generation of $\mathrm{Ca} 2+$ signals in plants annual. Annual Review of Plant Biology Vol. 55:401-427 https://doi.org/ 10.1146/annurev.arplant.55.031903.141624

8. Hetherington AM, lan Woodward F (2009) Access : the role of stomata in sensing and driving environmental change : nature the role of stomata in sensing and driving environmental change. Nature 424(August):6951-6951 https://doi.org/10.1038/nature01843

9. Scrase-Field, Sarah A.M.G., and Marc R. Knight. 2003. Calcium: just a chemical switch? Current Opinion in Plant Biology 6 (5): 500-506. https://doi.org/10. 1016/S1369-5266(03)00091-8.

10. Weinl, Stefan, and Jo"rg Kudla. 2017. Joint pilot sequence design and power control for Max-Min fairness in uplink massive MIMO. IEEE International Conference on Communications, 517-528. https://doi.org/10.1109//CC.2017.7996780.

11. Murashige T, Skoog F (1962) A revised medium for rapid growth and bio assays with tobacco tissue cultures. Physiologia Plantarum 15:473-497

12. Ambrosius S, Gundlach H, Kieser J (1996) Thermische Verwertung von Zementgebundenen Asbestprodukten in Zementöfen. ZKG International 49(8):444

13. Herrera-Estrella L, Depicker A, Van Montagu M, Schell J (1983) Expression of chimaeric genes transferred into plant cells using a Ti-plasmid-derived vector. Nature 303(5914):209-213 https://doi.org/10.1038/303209a0

14. Mahajan S, Tuteja N (2005) Cold, salinity and drought stresses: an overview. Archives of Biochemistry and Biophysics 444(2):139-158 https://doi.org/10. 1016/j.abb.2005.10.018

15. Doyle JJ, Doyle JL (1987) A rapid DNA isolation procedure for small quantities of fresh leaf tissue. Phytochemical Bulletin 19(1):11-15

16. Gambley, Rhonda L, Rebecca Ford, and Grant R Smith. 1993. Microprojectile transformation of sugarcane meristems and regeneration of shoots expressing Fl-glucuronidase. Plant Cell Reports (1993) 12: 343-346.

17. Hossain, S. N., M. K. Munshi, M. R. Islam, L. Hakim, and M. Hossain. 2003. In vitro propagation of plum (Zyziphus Jujuba Lam.) 13 (1): 81-84.

18. Hiei Y, Ohta S, Komari T, Kumashiro T (1994) Efficient transformation of rice (Oryza Sativa L.) mediated by agrobacterium and sequence Analysis of the boundaries of the T-DNA. Plant J 6(2):271-282 https://doi.org/10.1046/j. 1365-313X.1994.6020271.X

19. Sahoo, Rupam, Rajib Sengupta, and Sanjay Ghosh. 2003. Nitrosative stress on yeast: inhibition of glyoxalase-l and glyceraldehyde-3-phosphate dehydrogenase in the presence of GSNO. Biochemical and Biophysical Research Communications 302 (4): 665-670. https//doi.org/10.1016/50006-291X(03)00251-1.

20. Karami O (2008) Transgenic Plant Journal @2008 Global Science Books Factors Affecting Agrobacterium-Mediated Transformation of Plants

21. Hiei Y, Komari T (2008) Agrobacterium-mediated transformation of rice using immature embryos or calli induced from mature seed. Nature Protocols 3(5):824-834 https://doi.org/10.1038/nprot.2008.46 
22. Raja NI, Bano A, Hamid R, Haroon Khan M, Chaudhry Z (2009) Efeect of age of embryogenic callus on plant regeneration in local cultivars of wheat (Triticum Aestivum L.). Pakistan J Botany 41 (6):2801-2806

23. Bartlett, Joanne G, Sílvia C Alves, Mark Smedley, John W Snape, and Wendy A Harwood. 2008. High-throughput agrobacterium-mediated barley transformation 12: 1-12. https://doi.org/10.1186/1746-4811-4-22.

24. Shrawat, A.K., D. Becker, and H. Lörz, Agrobacterium tumefaciens-mediated genetic transformation of barley (Hordeum vulgare L.). Plant Science, 2007. 172(2): p. 281-290

25. Zuraida, Ab Rahman, Ahmad Seman Zulkifli, Basirun Naziah, Lizah Julkifle Advina, Zainal Zamri, and Subramaniam Sreeramanan. 2011. Preliminary investigations of agrobacterium-mediated transformation in indica rice MR219 embryogenic callus using gusa gene." African Journal of Biotechnology 10 (40): 7805-7813. https://doi.org/10.5897/ajb10.1436

26. Xing Y, Yang Q, Ji Q, Luo Y, Zhang Y, Ke G, Wang D (2007) Optimization of agrobacterium-mediated transformation parameters for sweet potato embryogenic callus using $\beta$-glucuronidase (GUS) as a reporter. African Journal of Biotechnology 6(22):2578-2584

27. Almeida WA, Mourão Filho FD, Mendes BM, Pavan A, Rodriguez AP (2003) Agrobacterium-mediated transformation of Citrus sinensis and Citrus limonia epicotyl segments. Scientia Agricola 60(1):23-29 https://doi.org/10. 1590/s0103-90162003000100005

28. Cho MJ, Jiang W, Lemaux PG (1998) Transformation of recalcitrant barley cultivars through improvement of regenerability and decreased albinism. Plant Science 138(2):229-244 https://doi.org/10.1016/S0168-9452(98)00162-9

29. Ali S, Mannan A, El Oirdi M, Waheed A, Mirza B (2012) Agrobacteriummediated transformation of rough lemon (Citrus jambhiri Lush) with yeast HAL2 gene. BMC Res Notes 5(1):1 https://doi.org/10.1186/1756-0500-5-285

30. Prodhan SH, Hasan N, Hammadul H, Alam SS, Raqibul M, Gupta A, Ummay M, Khatun S, Parvin A, Faruque Z (2016) Development of an efficient in vitro regeneration system for endangered wild orange. Citrus chrysocarpa L. 4531(October 2017):187-196

31. Hasan R, Mohammed AG, Hasan MN, Rejwan HM, Hasan R, Prodhan SH (2016) Efficient regeneration system for the improvement of Kinnow Mandarin (Citrus reticulata Blanco). Journal of Biology 6(7)

32. Hasan R, Mohammed AG, Hasan MN, Fahim SM, Rejwan HM, Shamim MA, Siddique MAT, Prodhan SH (2016) Efficient callus initiation and plantlet regeneration of Citrus japonica Margarita. IOSR Journal of Pharmacy and Biological Sciences 11(04):72-78 https://doi.org/10.9790/3008-1104037278

\section{Publisher's Note}

Springer Nature remains neutral with regard to jurisdictional claims in published maps and institutional affiliations.

\section{Submit your manuscript to a SpringerOpen ${ }^{\circ}$ journal and benefit from:}

- Convenient online submission

- Rigorous peer review

- Open access: articles freely available online

- High visibility within the field

- Retaining the copyright to your article

Submit your next manuscript at $\boldsymbol{\nabla}$ springeropen.com 